\title{
MEASURING THE EFFICIENCY OF LOCAL GOVERNMENT AGENCIES STRUCTURE: FINDING RIGHT SIZING PATTERNS
}

\author{
Halilul Khairi \\ Fakultas Politik Pemerintahan, Institut Pemerintahan Dalam Negeri \\ Jl. Raya Bandung-Sumedang KM. 21 Jatinangor, 456363 \\ E-mail: halilulipdn@gmail.com
}

\begin{abstract}
The purpose of this study is to determine whether the current bureaucratic structure is efficient and is actually formed to carry out managerial functions according to the needs of the tasks and functions that are carried out. This research also aims to find out that the formulation of job descriptions in structural positions has been formulated in accordance with the standard of job description formulation. Descriptive quantitative method is used to measure the structural workload of structural work units and the qualitative method is used to determine the pattern of structural job description description in the regional apparatus. An important finding in this study is that the formulation of the job description does not meet the standard rules where the task description does not contain content, methods and results / objectives. The formulation of echelon IV job descriptions also does not reflect structural task behavior patterns that describe managerial behavior. The task formulation still uses the same or even lower pattern of task behavior than the staff behavior pattern. Another important finding is that the main managerial workload in echelon IV work units generally falls into the very low workload category. So that, it can be concluded that the organizational structure at echelon IV level is less efficient because it carries out tasks whose job behavior patterns can be carried out by staff.
\end{abstract}

Keywords: Bureaucracy Structure; Managerial Task; Managerial Workload.

\section{MENAKAR EFISIENSI STRUKTUR PERANGKAT DAERAH: MENEMUKAN POLA PENGORGANISASIAN YANG TEPAT UKURAN (RIGHT SIZING)}

\begin{abstract}
ABSTRAK. Tujuan dari penelitian ini adalah untuk mengetahui apakah struktur birokrasi yang ada saat ini sudah efisien dan benar-benar dibentuk untuk melaksanakan fungsi manejerial sesuai kebutuhan tugas dan fungsi yang diselenggaran. Penelitian ini juga bertujuan untuk mengetahui perumusan uraian tugas pada jabatan struktural sudah dirumuskan sesuai dengan standar perumusan uraian tugas. Metode kuantitatif deskriptif digunakan untuk mengukur beban kerja manejerial unit kerja struktural dan metode kualitatif digunakan untuk mengetahui pola perumusan uraian tugas jabatan struktural ada perangkat daerah. Temuan penting dalam penelitian ini adalah bahwa perumusan uraian tugas belum memenuhi kaidah standar dimana dalam rumusan uraian tugas belum mengandung isi, cara dan hasil/tujuan. Rumusan uraian tugas eselon IV juga belum mencerminkan pola perilaku tugas struktural yang menggambarkan perilaku manejerial. Rumusan tugas masih menggunakan pola perilaku tugas yang sama atau malah lebih rendah dari pola perilaku staf. Temuan penting lainnya adalah bahwa beban kerja utama manejerial pada unit kerja eselon IV pada umumnya masuk dalam kategori beban kerja sangat rendah. Dengan kondisi tersebut, maka dapat disimpulkan bahwa struktur organisasi pada level eselon IV kurang efisien karena melaksanakan tugas yang pola perilaku tugasnya dapat dilaksakan oleh staf.
\end{abstract}

Kata kunci: Struktur Birokrasi; Efisiensi; Tugas Manejerial; Beban Kerja Manejerial.

\section{INTRODUCTION}

Government agency structure has been changed since the new era rezim. Eventhough the model has changed, the paradigm of uniformity pattern on region and administrative affairs remains same. During the new era rezim, the pattern of government agencies is almost same both in type and size. Most of government agencies only focus on basic function task, and a few number of them that focus on working on additional functions.

In reformation era, some of central government affairs were delivered to local government through the law number 22 Year 1999 on Local Government. As a result, the model of government agency structure has also been amendment.

In the earlier reform, Head of Government Agency position that should be led by eselon III/b has shifted into led by eselon II/b, also there was a new position formed namely Deputy of Head Department. Meanwhile, during the reformation, the structure of Government Agency also has changed several times. Firstly, the alteration is shown through the shift of Government Regulation number 84 year 2000 into Government Regulation Number 8 Year 2003 concerning on Guidelines for Regional Organisation Units. Secondly, the amandment of Law Number 22 year 1999 on Local Government into Law number 32 Year 2004 about Local Government also has affected to transformation of Guidelines for regional agency. As a result, Government Regulation Number 84 year 2000 has been repealed, and replaced by Government Regulation number 41 year 2007 on Guidelines for Regional Organisation Units.

The establishment of the Law number 23 Year 2014 on Local Government also has implied to the emergence of Government Regulation number 18 year 2016 concerning on government agency structure transformation. Based on the regulation, government agency is defined as organisation on local government who has responsibility 
to Head of Regency through Regional Secretary in delivering services in local level. Government agency is formed to deliver the function of government afffairs. The form of government agency consists of: a) Regional Secretariat; b) Secretariat of Regional Representative Assembly; c) Inspectorate; d) Agency; e) Body; f) District (for regency/city).

Regional secretariat, has a duty in assisting Head of Regency/Province to formulate policy and to organise the administrative functions of government agency and also in delivering services. Secretariat of Regional Representative Assembly has a duty to deliver administrative functions of secretary and finance adminstration, to support the activities and functions of legislative members, and to provide and manage the skilled employees in assising legislative members based on the need. Meanwhile, Regional inspectorate has a duty to support Head of Regency/ Province in managing and supervising the implementation of administrative affairs and co-administration task of government agency. Furthermore, Agency has dealing with administrative affairs under its authority.

Regional authority is classified into 3 (three) types based on the workloads taken care. Type A is formed for heavy, Type $\mathrm{B}$ for medium and type $\mathrm{C}$ for small amount of job/task. To improve the quality of work, coordination, service delivery, and community empowerment on Village/Urban Village, government have formed District in regency/city level. District was formed with due observance to the provision of basic, technical administrative requirements. District also has classified into 2 (two) types namely type A and B based on the amount of task/duty.

A grouping of the organization units is based on a conception of the formation of an organization. It consists of 5 (five) elements according to Minzberg such as regional head and deputy as the leader of the top level (strategic apex), regional secretary as a liaison middle (middle line), agency as a main executor (operating core), body as a supporting for other agencies (technostructure), and secretariat as supporting workforce (H. P. Mintzberg, 1983:3-6). In the context of creating the formation of units in accordance with the organisation design, formation of Government authority is arranged under government regulation based on the principle of efficiency, effectiveness, discharged of duty, range control, clear review performance management, flexibility, administrative matters for local authority, and intensity of administrative matters and the potential of the region.

The main elemen of the formation of government agency is seen through the government task transferred to the regions which consist of mandatory and supplementory/ optional affairs. The compulsory affairs is divided into two categories namely basic social services and nonbasic social services. In addition, based on distribution on government affairs/power between Central Government and Provinces and Districts/Cities as mentioned on division of power/affairs on concurent affairs, Local government is responsible in managing the facilities, personnel/staff, method and function of work such as planning, organising, budgeting, supervision, research and development, standardising and managing the information according to government affairs substance.

The formation of units is considered by area, population, local and the fiscal capacity the workload in accordance with administrative matters that transferred to the regions as every mandate must be implemented. The type units based on calculations of the number of the workload variables. variable load work consisting of general variables and technical variables. Common variables are covering population, the number of regional budget with weights of $20 \%$ (twenty percent) and technical variables as the main measurement with the weight $80 \%$ (eighty percent).

In every variable, both the general and the technical variable is determinde by 5 class of interval, started with 200 to 1000. Each Agency and body is consisted of the Head, secretary/department and sub department/section/ subsection. The maximum number of agency/body is 4, except for special affairs could be upgrade to 6 . Regional Province Secretariat consist of 5 levels namely Regional Secretary, Regional Assistant, Bureau, Division and Subdivision. Regional Regency Secretariat consist of 4 level that same as the structure of the Regional Province Secretariat without the Bureau level. Regional Inspectorate only have 2 units namely Inspector and Assistant Inspector.

Even though the reform of government agencies has arised, the size remains same (based on hierarchy and ineffiecnt in size). The reform in 1997 unsuccessful in delivering efficient bureaucracy, moreover decentralization has given the phenomena of bureaucracy being too large in size. With Law number 22 years 1999 on local government and followed by government regulation number 84 year 2000 has submitted 34 administrative matters as regional autonomy. With the policy of the decentralization, Local Government may establish units in accordance with administrative matters that transferred to the regions. To strengthen regional autonomy, agencies (kanwil) and the office of the vertical dissolved and units raised its eselon by two levels namely echelon III/A raised into echelon II/A and echelon III/b raised into echelon II/B and so on to echelon underneath it. Although echelon raised two levels, but the level of the structure of work remain unchanged in three to five level. For example the provincial agency officer formerly led by head of echelon III/A supervising head of echelon IV/A, also Head of Division echelon IV/A supervising Head of Sub Division echelon V/A. However, in the new structure, with the same structure, they only change the echelon in with for Head of Agency led by echelon II/A, Head of Division led by echelon III/A and Head of Subdivision led by IV/A. Based on those issues, it is assumed that The echelon as a class are not really instumen, in designing the structure of the organization 
but the main purpose is to design a structure of salaries (Poels, 2003:2).

The use of the organizational structure of the hierarchy model, apart from being inefficient, it will affect to the additional of coordination so that the execution of a task to be slow and infficient in time. The determination of "eselonisasi" (determine the echelon level) should be used as policy in awarding employees based on the value of some variable attached to post with it (Walker \& Brewer, 2008:3).

Through the government regulation no 100 years about Assignation of Civil Servants Into Structural Position, the level of post office job is divided into 8 levels and there is an article of removing the echelon $\mathrm{V}$, however in Government Regulation Nomber 26 Year 2007, the level of office job the level of office job is divided into 9 levels which is included echelon V/A. The number of the level of echelon is often translates as the maximum of the level of a structure in an organization that results in the number of the level of on each offices and work units of vary according to policy set for the offices and work of units. On the central office of the ministry/institution in general use 4 managerial level. While for local government agencies use 3 levels managerial except for Regional Secretariat of Province and Regional Secretariat of Regency that has 5 and 4 levels of manajerial officers.

The level of the structure of the organization government offices of central and local government is not currently based on analysis management needs of the duties, instead it is determined based on uniformity model between one agency to other institutions (Martini, Tahir, $\&$ Khairi, 2019:7). The uniformity of the organization structure policy is also applied in each local region. The structural is managerial job that has a duty in supervise and coordinate the duties of the employee in beneath it (H. Mintzberg, 1980:12). The number of managerial job is determined by span of control on staff or employee (Gibson, Ivancevich, \& Donnelly, 1994:30) menawhile, the numbe of span of control on subordinate is based on the characteristic of job desk and the supervision methods used. A routine, similar, regular and lied in one location, or a duty within based on expertise needs low independent supervision so that the number of span of control is much higher (Gibson et al., 1994:32). While, the dynamic, standardize and need decision-making to the chairman need higher supervision, so that the span of control remains lower. The Supervision method also determines the span of control. Work processing data that uses information technology or work that can be supervised using ratio analysis on input and output does not require highjy direct supervision so that the span of control needed is higher (Hardiyansyah \& Rachmawati, 2018:1).

Otherwise, the work cannot be helped by information technology or work that have difficulties in standarized (input-output) has lom on span of control due to require high supervision.
Hence, it is arguably that each unit that has different job characteristic and supervision method one to another should also have different structure. Indonesia currently has 460.067 structural positions or equivalent to $11 \%$ of the civil servants in indonesia consisting of the echelon 1 and 2 echelon about 20.038, while echelon 3 and 4 about 440.029 positions. Characteristic of government services based on monopolistic would encourage the establishment of inefficient and ineffectual government structure (Burton, Borge, \& Geraldin, 2011:1).

This study aims to analyze the need of bureaucratic structure in the level of local government. this research is expected able to illustrate the role and the real workload conducted by the lowest level of bureaucracy (echelon IV) on units in local level. By knowing workload manejerial on the structure of the lowest can be analyzed and drawn conclusion needs level or tiers structure bureaucracy in regional .This report is written with menganlisis workload manejerial to structure the lowest in regional.

By knowing managerial workload on the minor level, the need of bureaucracy structure on local government level could be analyzed and determined. The study is carried out by analyzing the managerial workload on the lowest level of local government agencies. It is shown that the workload analysis on the minor level (echelon IV) currently have not focused on the function of managerial affairs, hence, the need of structur of bureaucracy do not covered. With this managerial workload analysis, it is expected to have the real data of the need of bureaucracy structure on local government agencies.

\section{METHOD}

This research is conducted in Sub Agency of Education in DKI Jakarta Province as a representative of special regions, some local agencies representing regency and Cimahi representing the City. This research is carried out from May to September 2019.

This research has undertaken using mixed method in which descriptive quantitative used for measuring managerial workload of echelon IV, while qualitative applied in analyzing the proper formulation of job description of echelon IV as the caretaker of the managerial functions in minor level. Measurement of the managerial workload is carried out through some steps. First, the effective workload for civil servants including echelon IV is as much 1250 hours in one year in accordance with the regulation of Minister of Home Affairs number 12 years 2017 about The Formation of Technical Unit and Branches of the Sub Agency. Second, the effective work hours above is divided between mandatory and additional duty. The main role of mandatory duty is the caretaker should provide goods/services for society or other units related. While supplementary duty is related with routine administrative affairs as well as capacity building activity. The implementation of additional workload should not 
be more than the main workload practice. The workload has set as 375 working hours effective in a year derived from the routine activities for 1.25 hours a day or in other words it is same as 315 working hours effective in a year plus capacity building as many as 12 days or 60 hours in a year. The categorized supplementary programs consist of activities that does not bear an output relating to goods and services delivery to the community or other units, for instance meeting, giving directions to employees/ staffs, preparing daily, monthly and annualy reports, also prepared equipment work, financial administration and capacity building. Meanwhile, it is underlined that the main managerial workloads are not designed for minor level or functional position. The number of the main managerial workload is equivalent to 875 working hours effective in one year. Measurement result is classified into four categories with the highest score of above 875, high with value $750-875$, medium with $600-750$, lower 500 600 and the lowest with a value less than 500 .

Third, measurement on main workload is conducted by completing the form with its guidance for echelon IV is derived from analyzing job description. Fourth, the completed form is verified by researchers and the authorized units for validating the responses on main activity such as its activity, volume and time duration. Fifth, the validated responses of the main activity is measured and analyzed. The last, the result is valued/rated and it is classified and summarized based on the unit assessed. The analysis of the accuracy of formulation of Job description of echelon IV in dealling with the managerial function is carried out by comparing the behaviour/model of the the routine task generally. The behaviour/model of the daily task is characteristic of duty managed by the job holder. Managerial duty related with the function of management plan target covering setting up the work planning, coordinating work implementation, organizing works, controlling the procces and the final achievements of goal setting. The duty listed does not suit with the managrial function sre incompstible with the behaviour of job holder of ecehelon IV.

\section{RESULTS AND DISCUSSION}

Formal organization as a system of activities that are consciously coordinated by two or more people (Barnard, 2006:3). By this definition, said system and people. People, not boxes on an organizational chart, establish a formal organization. The organizational structure is rooted in the organization's recognition of the need to formally coordinate the interaction patterns of organizational members (Robbins, 1994:12). Coordination is carried out by the head of the work unit in stages through four ways of coordinating in the organization, which include mutual adjustment, direct supervision, and standardization. (H. Mintzberg, 1980:3-6).
Analysis of the efficiency of the local government bureaucratic structure will provide a real picture of the role and contribution of the bureaucratic structure in carrying out management functions to carry out regional authority. A bureaucracy that is too fat will result in not only wastefulness, but also sluggishness, overlapping, and conflicts of authority that can hinder the achievement of goals and reduce the quality of public services (Ghiselli \& Siegel, 1972:4) (Porter \& Siegel, 1965:4). The results of this study indicate that the formation of bureaucratic structures is not based on considerations of managerial needs for managing tasks and functions, but tends to be based on fulfilling the mandate of legislation (legality principle). (Walker \& Brewer, 2008:2). The formation of sections, subsections, subsections is carried out because regulations provide space to be formed, as well as the number of structures determined based on the amount permitted by statutory regulations. The formulation of job descriptions for structural officers also does not reflect the implementation of managerial functions and some job descriptions are not formulated in accordance with the standard of job description formulation. In several interviews it was seen that structural officials were unable to explain the outputs of the job descriptions they carried out.

\section{A. Formulation of job descriptions}

Job descriptions are descriptions or expansions of all job duties which are the main efforts made by office holders in processing work materials into work results using work instruments and under certain conditions of implementation. Job descriptions must meet the following requirements: First, content, namely the objects carried out by the task holder. Second, the way to describe the techniques or methods used to carry out the task. Third, the objective is the result to be obtained from the implementation of the task. To ensure a job description formulation meets the requirements or standards is to ask questions, namely what (what), what is done by the incumbent, how (how), how are the incumbents used in carrying out their duties, and why (why), to produce what the work is carried out. Based on the job descriptions obtained on the research object, some formulations of job descriptions as samples were analyzed as described in the following table 1 .

The aforementioned job descriptions are formulated in DKI Jakarta Governor Regulation Number 277 of 2016 concerning the Organizational Structure and Work Procedure of the DKI Jakarta Education Office. Although only one job description is taken for each work unit, the overall job description contained in this Governor Regulation has relatively the same formula. From the formulation of the job description, no clear objects are drawn, for example compiling strategic plan materials, what are the concrete objects, whether to collect data and analyze data? or just put it in writing, it is also unclear 
whether the material is in the form of secondary data or primary data? Apart from unclear content, there is also absolutely no method or method of carrying out the task. In the formulation of job descriptions, there are no results produced by the duty holder. If these three elements are absent, then the workload carried out by the office holder cannot be formulated, because the workload can only be measured if the object is clear, the method is clear and the results are clear. The results must be calculated in quantitative terms because they will be used to calculate the volume of tasks in the workload analysis, while the methods and job descriptions will determine the length of time required to produce each result / goal.

Similar to the pattern of job descriptions that are carried out at the DKI Jakarta Education Office, the formulation of job descriptions in West Bandung Regency and Cimahi City also does not meet the requirements and standards in the formulation of job descriptions. Some job descriptions in West Bandung Regency and Cimahi City can be seen in the following on table 2 .

\section{Table 1. Analysis of the suitability of the formulation of duties of the DKI Jakarta Education Office}

\begin{tabular}{|c|c|c|c|}
\hline No & Work unit & Job description & Interpretation \\
\hline 1 & Secondary Education Section & $\begin{array}{l}\text { Prepare materials for strategic plans and work plans } \\
\text { for official tribes }\end{array}$ & $\begin{array}{l}\text { Does not contain content, methods and } \\
\text { objectives / results. }\end{array}$ \\
\hline 2 & AUD and DIKMAD sections & $\begin{array}{l}\text { Carry out the process of assessing, analyzing and } \\
\text { reporting the results of the Regional Standard School } \\
\text { Examinations }\end{array}$ & $\begin{array}{l}\text { Does not contain content, methods and } \\
\text { objectives / results. }\end{array}$ \\
\hline 3 & $\begin{array}{l}\text { Basic Education and PKLK } \\
\text { Section }\end{array}$ & $\begin{array}{l}\text { Carrying out the student journalism work } \\
\text { competition (LKJS) for junior high school students } \\
\text { at the regional education sub-department level II, } \\
\text { Central Jakarta }\end{array}$ & $\begin{array}{l}\text { Does not contain content, methods and } \\
\text { objectives / results. }\end{array}$ \\
\hline 4 & $\begin{array}{l}\text { Educators and Education } \\
\text { Personnel Section }\end{array}$ & $\begin{array}{l}\text { Carry out PTK Field Work Meetings regarding } \\
\text { performance achievements as well as sharing about } \\
\text { obstacles in carrying out tasks and finding solutions } \\
\text { together }\end{array}$ & $\begin{array}{l}\text { Does not contain content, methods and } \\
\text { objectives / results. }\end{array}$ \\
\hline 5 & $\begin{array}{l}\text { Education Infrastructure and } \\
\text { Assets Section }\end{array}$ & Carry out activities according to the budget ceiling & $\begin{array}{l}\text { Does not contain content, methods and } \\
\text { objectives / results. }\end{array}$ \\
\hline
\end{tabular}

Source: Education Office 2019 (processed)

Table 2. Suitability Analysis of Job Description Formulation West Bandung Regency

\begin{tabular}{|c|c|c|c|}
\hline No & Work unit & Job description & Interpretation \\
\hline \multicolumn{4}{|c|}{ West Bandung } \\
\hline 1 & $\begin{array}{l}\text { Sub Division of Spatial } \\
\text { Planning and Environmental } \\
\text { Development Planning Agency }\end{array}$ & $\begin{array}{l}\text { Preparing the Implementation of Musrenbang } \\
\text { RPJPD, RPJMD and RKPD for Public Works, and } \\
\text { Transportation. }\end{array}$ & $\begin{array}{l}\text { Does not contain content, methods } \\
\text { and objectives / results. }\end{array}$ \\
\hline 2 & $\begin{array}{l}\text { Prevention Section, Disaster } \\
\text { Management Agency }\end{array}$ & $\begin{array}{l}\text { Carry out the Compilation of Materials and Facilitation } \\
\text { for Disaster Prevention from related fields / work units } \\
\text { within the Regional Disaster Management Agency in } \\
\text { accordance with applicable regulations; }\end{array}$ & $\begin{array}{l}\text { Does not contain content, methods } \\
\text { and objectives / results. }\end{array}$ \\
\hline 3 & $\begin{array}{l}\text { Pioneer Youth Section, Youth } \\
\text { Entrepreneurs and Youth Cadres, } \\
\text { Youth and Sports Agency }\end{array}$ & $\begin{array}{l}\text { Designing the needs for the implementation of the } \\
\text { flag-raising troops (Paskibraka) at the district level }\end{array}$ & $\begin{array}{l}\text { Does not contain content, methods } \\
\text { and objectives / results. }\end{array}$ \\
\hline 4 & $\begin{array}{l}\text { Educators and Education } \\
\text { Personnel Section }\end{array}$ & $\begin{array}{l}\text { Conducting PTK Field Work Meetings regarding } \\
\text { performance achievements as well as sharing about obstacles } \\
\text { in carrying out tasks and finding solutions together }\end{array}$ & $\begin{array}{l}\text { Does not contain content, methods } \\
\text { and objectives / results. }\end{array}$ \\
\hline 5 & $\begin{array}{l}\text { Section of Planning and } \\
\text { Environmental Impact } \\
\text { Assessment, Environment Agency }\end{array}$ & $\begin{array}{l}\text { Preparation of district strategic environmental study } \\
\text { materials }\end{array}$ & $\begin{array}{l}\text { Does not contain content, methods } \\
\text { and objectives / results. }\end{array}$ \\
\hline \multicolumn{4}{|c|}{ Cimahi City } \\
\hline 1 & $\begin{array}{l}\text { Social Empowerment and } \\
\text { Poverty Reduction Section }\end{array}$ & $\begin{array}{l}\text { Designing an integrated referral service system and } \\
\text { social welfare center }\end{array}$ & $\begin{array}{l}\text { Does not contain content, methods } \\
\text { and objectives / results. }\end{array}$ \\
\hline 2 & $\begin{array}{l}\text { Social Protection and Security } \\
\text { Section }\end{array}$ & Processing Displaced Persons recommendations & $\begin{array}{l}\text { Does not contain content, methods } \\
\text { and objectives / results. }\end{array}$ \\
\hline 3 & Social Rehabilitation Section & $\begin{array}{l}\text { Carry out service activities and social guidance for } \\
\text { neglected elderly }\end{array}$ & $\begin{array}{l}\text { Does not contain content, methods } \\
\text { and objectives / results. }\end{array}$ \\
\hline 4 & $\begin{array}{l}\text { Population control, extension } \\
\text { and mobilization sections }\end{array}$ & Prepare facilities and infrastructure for activities & $\begin{array}{l}\text { Does not contain content, methods } \\
\text { and objectives / results. }\end{array}$ \\
\hline 5 & Family Planning Section & $\begin{array}{l}\text { Carry out family planning services for the } \\
\text { installation of IUD contraceptives and implants }\end{array}$ & $\begin{array}{l}\text { Does not contain content, methods } \\
\text { and objectives / results. }\end{array}$ \\
\hline
\end{tabular}

Source: Organization Section, West Bandung Regency and Cimahi City, 2019 (processed). 
Based on the table above, it can be seen that the pattern of job description formulation in West Bandung Regency is not much different from the pattern of job description formulation at the DKI Jakarta Education Office. The pattern for drafting job descriptions has actually been regulated in the Minister of Home Affairs Regulation Number 35 of 2012 concerning Position Analysis within the Ministry of Home Affairs and Local Government. In the attachment to the Regulation it is well explained that each job description must contain content (what), how (how) and objectives / results (why). As is the case with the DKI Jakarta Education Office, the formulation of job descriptions in the regional apparatus (secretariat, service, agency and inspectorate) in the West Bandung Regency Government will also be difficult and very subjective in calculating the workload due to unclear methods / methods of work and work results from each job description. The same pattern of job description formulation is also found in regional apparatus in Cimahi City which can be seen the pattern of formulating job descriptions at the Social and Family Planning Office of Cimahi City is not much different from the pattern used by the DKI Jakarta Government and the West Bandung Regency Government.

The conditions in these three regional governments prove that the regional government does not formulate job descriptions in accordance with the standards and guidelines set out in the Minister of Home Affairs Regulation Number 35 of 2012 so that the measurement of workloads that departs and is based on job descriptions of difficult standards can be carried out regularly. objective in accordance with the standard method established in calculating the workload of bureaucratic structures in regional apparatus. Based on the results of interviews with the Head of the Organization Section of the Regional Secretariat of West Bandung Regency as well as interviews with the Head of the Cimahi City Organization Section, it is known that the measurement of the workload of each position is left to the respective office holders and there is no process of verification and proof of the correctness of the workload filled by each of these office holders (self-assessment). With this self-assessment pattern, the subjectivity factor of the office holder cannot be avoided. So, in this study the researchers did not use self-assessment alone in measuring the work unit's managerial workload, but also verified through the audit method where the researcher directly verified the correctness of the tasks carried out, evidence of work results and the methods used in carrying out each job description. with the audit method, it will be possible to know the correctness of the managerial workload possessed by each echelon IV structural official on the research object.

In addition to the pattern of job description formulation that is not in accordance with the applicable standards in the formulation of job descriptions, the pattern of task behavior in structural positions also does not reflect managerial duties. The behavior pattern of managerial tasks should contain indicators of management functions, namely setting target plans, forming teams / dividing work, directing / giving directions, checking / correcting / assessing, supervising / monitoring, reporting (Suparman, Chandra, \& Sarri, 2019:1). Based on the job descriptions in table 2 and table 3 above, it is known that almost none of the formulas for echelon IV job descriptions contain patterns of manager behavior. For more details, see the following table 3 .

The description of the above tasks is lower in the behavior pattern of their duties when compared to the behavior patterns of staff duties stipulated in the Regulation of the Minister of PAN and RB Number 41 of 208 concerning Nomenclature of Executing Positions for Civil Servants in Government Agencies. The behavior pattern of staff duties regulated in the Minister of PAN and $\mathrm{RB}$ regulations contains elements of analyzing, analyzing and formulating recommendations. For example, a job description for one of the staff positions in the PAN and $\mathrm{RB}$ Permen is a Risk Management Analyst with job descriptions: Conducting analysis and review activities in order to formulate recommendations in the field of risk management. Meanwhile, the behavior pattern of the structural duties of echelon IV officials generally only "carries out". Thus it can be concluded that the pattern of formulating job descriptions for echelon IV structural officials also does not reflect the behavior pattern of structural officials as executors of managerial functions.

\section{B. Managerial Workload}

Managerial workload analysis is carried out on echelon IV officials to determine the main workload which is actually carried out by each echelon IV official. Based on the results of the evaluation of the main workload at the DKI Jakarta Education Sub-department, it is found that the main managerial workloads of each echelon IV are as follows on Table 4.

Table 4. Main Workload Section of the Central Jakarta Education Sub-Department

\begin{tabular}{|c|c|c|c|c|}
\hline No & Work unit & $\begin{array}{c}\text { Main } \\
\text { Workload } \\
\text { Delivered }\end{array}$ & $\begin{array}{c}\text { Main } \\
\text { Workload } \\
\text { Result of } \\
\text { Verification }\end{array}$ & Category \\
\hline 1 & $\begin{array}{l}\text { Secondary } \\
\text { Education Section }\end{array}$ & 1616 & 414,5 & Very low \\
\hline 2 & $\begin{array}{l}\text { PAUD and } \\
\text { DIKMAS } \\
\text { sections }\end{array}$ & 3619 & 332 & Very low \\
\hline 3 & $\begin{array}{l}\text { Educators and } \\
\text { Education } \\
\text { Personnel } \\
\text { Section }\end{array}$ & 1324 & 335 & Very low \\
\hline 4 & $\begin{array}{l}\text { Education } \\
\text { Infrastructure } \\
\text { and Assets } \\
\text { Section }\end{array}$ & 9340 & 110 & Very low \\
\hline 5 & $\begin{array}{l}\text { Basic Education } \\
\text { Section and PKLK }\end{array}$ & 9864 & 357 & Very low \\
\hline
\end{tabular}

Source: Primary Data (processed) 
Table 3. Analysis of the Behavior Patterns of Echelon IV Officials in the DKI Jakarta Education Office, Regional Apparatus of Cimahi City and Regional Apparatus of West Bandung Regency

\begin{tabular}{|c|c|c|}
\hline No & Work unit & Job description \\
\hline 1 & Secondary Education Section & $\begin{array}{l}\text { Prepare materials for strategic plans and } \\
\text { work plans for official tribes }\end{array}$ \\
\hline 2 & AUD and DIKMAD sections & $\begin{array}{l}\text { Carry out the process of assessing, } \\
\text { analyzing and reporting the results of the } \\
\text { Regional Standard School Examinations }\end{array}$ \\
\hline 3 & $\begin{array}{l}\text { Basic Education and PKLK } \\
\text { Section }\end{array}$ & $\begin{array}{l}\text { Carrying out the student journalism } \\
\text { work competition (LKJS) for junior high } \\
\text { school students at the regional education } \\
\text { sub-department level II, Central Jakarta }\end{array}$ \\
\hline 4 & $\begin{array}{l}\text { Educators and Education } \\
\text { Personnel Section }\end{array}$ & $\begin{array}{l}\text { Carry out PTK Field Work Meetings } \\
\text { regarding performance achievements as } \\
\text { well as sharing about obstacles in carrying } \\
\text { out tasks and finding solutions together }\end{array}$ \\
\hline 5 & $\begin{array}{l}\text { Education Infrastructure and } \\
\text { Assets Section }\end{array}$ & $\begin{array}{l}\text { Carry out activities according to the } \\
\text { budget ceiling }\end{array}$ \\
\hline 6 & $\begin{array}{l}\text { Sub Division of Spatial } \\
\text { Planning and Environmental } \\
\text { Development Planning } \\
\text { Agency }\end{array}$ & $\begin{array}{l}\text { Preparing the Implementation of } \\
\text { Musrenbang RPJPD, RPJMD and RKPD } \\
\text { for Public Works, and Transportation. }\end{array}$ \\
\hline 7 & $\begin{array}{l}\text { Prevention Section, Disaster } \\
\text { Management Agency }\end{array}$ & $\begin{array}{l}\text { Carry out the Compilation of Materials } \\
\text { and Facilitation for Disaster Prevention } \\
\text { from related fields / work units within the } \\
\text { Regional Disaster Management Agency } \\
\text { in accordance with applicable regulations; }\end{array}$ \\
\hline 8 & $\begin{array}{l}\text { Pioneer Youth Section, Youth } \\
\text { Entrepreneurs and Youth } \\
\text { Cadres, Youth and Sports } \\
\text { Agency }\end{array}$ & $\begin{array}{l}\text { Designing the needs for the } \\
\text { implementation of the flag-raising troops } \\
\text { (Paskibraka) at the district level }\end{array}$ \\
\hline 9 & $\begin{array}{l}\text { Educators and Education } \\
\text { Personnel Section }\end{array}$ & $\begin{array}{l}\text { Conducting PTK Field Work Meetings } \\
\text { regarding performance achievements } \\
\text { as well as sharing about obstacles in } \\
\text { carrying out tasks and finding solutions } \\
\text { together }\end{array}$ \\
\hline 10 & $\begin{array}{l}\text { Section of Planning and } \\
\text { Environmental Impact } \\
\text { Assessment, Environment } \\
\text { Agency }\end{array}$ & $\begin{array}{l}\text { Preparation of district strategic } \\
\text { environmental study materials }\end{array}$ \\
\hline 11 & $\begin{array}{l}\text { Social Empowerment and } \\
\text { Poverty Reduction Section }\end{array}$ & $\begin{array}{l}\text { Designing an integrated referral service } \\
\text { system and social welfare center }\end{array}$ \\
\hline
\end{tabular}

12 Social Protection and Security Processing Displaced Persons Section recommendations

13 Social Rehabilitation Section

Carry out service activities and social guidance for neglected elderly

14 Population control, extension and mobilization sections

Prepare facilities and infrastructure for activities

Carry out family planning services for the installation of IUD contraceptives and implants
Interpretation

Does not contain managerial behavior patterns: setting target plans, forming a team / dividing work, directing / giving directions, checking / correcting / assessing, monitoring / monitoring, reporting

Does not contain managerial behavior patterns: setting target plans, forming a team / dividing work, directing / giving directions, checking / correcting / assessing, monitoring / monitoring, reporting

Does not contain managerial behavior patterns: setting target plans, forming a team / dividing work, directing / giving directions, checking / correcting / assessing, monitoring / monitoring, reporting

Does not contain managerial behavior patterns: setting target plans, forming a team / dividing work, directing / giving directions, checking / correcting / assessing, monitoring / monitoring, reporting

Does not contain managerial behavior patterns: setting target plans, forming a team / dividing work, directing / giving directions, checking / correcting / assessing, monitoring / monitoring, reporting

Does not contain managerial behavior patterns: setting target plans, forming a team / dividing work, directing / giving directions, checking / correcting / assessing, monitoring / monitoring, reporting

Does not contain managerial behavior patterns: setting target plans, forming a team / dividing work, directing / giving directions, checking / correcting / assessing, monitoring / monitoring, reporting

Does not contain managerial behavior patterns: setting target plans, forming a team / dividing work, directing / giving directions, checking / correcting / assessing, monitoring / monitoring, reporting

Does not contain managerial behavior patterns: setting target plans, forming a team / dividing work, directing / giving directions, checking / correcting / assessing, monitoring / monitoring, reporting

Does not contain managerial behavior patterns: setting target plans, forming a team / dividing work, directing / giving directions, checking / correcting / assessing, monitoring / monitoring, reporting

Does not contain managerial behavior patterns: setting target plans, forming a team / dividing work, directing / giving directions, checking / correcting / assessing, monitoring / monitoring, reporting

Does not contain managerial behavior patterns: setting target plans, forming a team / dividing work, directing / giving directions, checking / correcting / assessing, monitoring / monitoring, reporting

Does not contain managerial behavior patterns: setting target plans, forming a team / dividing work, directing / giving directions, checking / correcting / assessing, monitoring / monitoring, reporting

Does not contain managerial behavior patterns: setting target plans, forming a team / dividing work, directing / giving directions, checking / correcting / assessing, monitoring / monitoring, reporting

Does not contain managerial behavior patterns: setting target plans, forming a team / dividing work, directing / giving directions, checking / correcting / assessing, monitoring / monitoring, reporting 
Based on the table above, it is known that each echelon IV structural official proposed that their main workload was not based on empirical data and was even less rational. For example, the Head of the Infrastructure and Assets Section submits a main workload (outside of the supporting load) of 9340 hours, even though the employee workload for one year is only 1250 hours. This means that the Head of Education Infrastructure and Assets works more than 39 hours per day. However, after verification and audit of work evidence was carried out, the main workload drastically decreased from the workload delivered. Based on the main workload of the verification results, it is known that the main workload of echelon IV structural officials is all in the very low category. The workload of echelon IV structural officials becomes heavy because they carry out many jobs / tasks that are actually capable and become the job descriptions of the staff as described above. One of the reasons for the large number of staff work carried out by echelon IV structural officials is evident from the number of staff they supervise themselves. The number of civil servant staff for each section in the Central Jakarta II Education Office can be seen in the following table 5 .
Table 5. Number of Staff of Each Section in the Central Jakarta Education Sub-Department II

\begin{tabular}{|c|c|c|c|}
\hline No & Work unit & $\begin{array}{c}\text { Number of } \\
\text { Staff }\end{array}$ & Information \\
\hline 1 & Secondary Education Section & 4 & $\begin{array}{l}3 \text { PJLP } \\
\text { people }\end{array}$ \\
\hline 2 & PAUD and DIKMAS sections & 3 & $\begin{array}{l}3 \text { PJLP } \\
\text { people }\end{array}$ \\
\hline 3 & $\begin{array}{l}\text { Educators and Education } \\
\text { Personnel Section }\end{array}$ & 4 & $\begin{array}{l}3 \text { PJLP } \\
\text { people }\end{array}$ \\
\hline 4 & $\begin{array}{l}\text { Education Infrastructure and } \\
\text { Assets Section }\end{array}$ & 3 & $\begin{array}{l}3 \text { PJLP } \\
\text { people }\end{array}$ \\
\hline 5 & $\begin{array}{l}\text { Basic Education Section and } \\
\text { PKLK }\end{array}$ & 4 & $\begin{array}{l}3 \text { PJLP } \\
\text { people }\end{array}$ \\
\hline
\end{tabular}

Source: DKI Jakarta Education Agency 2019.

Meanwhile, the analysis of the main managerial workload at the Cimahi City Social, Family Planning, Women's Empowerment and Child Protection Office also shows that the workload of the workload is mostly very low. The main managerial workload of the Office of Social Affairs, Family Planning, Women's Empowerment and Child Protection in Cimahi City can be seen in the following table 6 .

Table 6. Main Managerial Workload of the Cimahi City Social, Family Planning, Women's Empowerment and Child Protection

\begin{tabular}{|c|c|c|c|c|}
\hline No & Work unit & $\begin{array}{l}\text { Main Workload } \\
\text { Delivered }\end{array}$ & $\begin{array}{c}\text { Main Workload Result of } \\
\text { Verification }\end{array}$ & Category \\
\hline \multicolumn{5}{|c|}{ Cimahi City } \\
\hline 1 & $\begin{array}{l}\text { Social Empowerment and Poverty } \\
\text { Reduction Section }\end{array}$ & 2118 & 600 & Moderate \\
\hline 2 & Protection and Social Security section & 1245 & 403 & Very low \\
\hline 3 & Social Rehabilitation Section & 3147 & 396 & Very low \\
\hline 4 & $\begin{array}{l}\text { Section Population Control, Education and } \\
\text { Mobilization }\end{array}$ & 1399 & 272 & Very low \\
\hline 5 & Family Planning Section & 2272 & 1.882 & Very high \\
\hline 6 & Family Resilience and Welfare Section & 1663 & 656 & Moderate \\
\hline 7 & $\begin{array}{l}\text { Section on Institutional Strengthening, } \\
\text { Gender and Child Data }\end{array}$ & 1729 & 176 & Very low \\
\hline 8 & $\begin{array}{l}\text { Section for Improving the Quality of Life } \\
\text { and Protection of Women }\end{array}$ & 1201 & 400 & Very low \\
\hline 9 & $\begin{array}{l}\text { Fulfillment of Rights and Child Protection } \\
\text { Section }\end{array}$ & 1411 & 426 & Very low \\
\hline \multicolumn{5}{|c|}{ West Bandung Regency } \\
\hline 1. & $\begin{array}{l}\text { Environmental impact study and planning } \\
\text { section }\end{array}$ & 5.404 & 315 & Very low \\
\hline 2. & Partnership section & 1.257 & 313 & Very low \\
\hline 3. & Environmental law compliance section & 4.806 & 168,3 & Very low \\
\hline 4 & Environmental monitoring section & 5.684 & 60,5 & Very low \\
\hline 5 & $\begin{array}{l}\text { Environmental conservation and } \\
\text { rehabilitation section }\end{array}$ & 826 & 110 & Very low \\
\hline 6 & $\begin{array}{l}\text { Waste, hazardous and toxic materials } \\
\text { management section }\end{array}$ & 2.300 & 513,3 & Low \\
\hline 7 & Solid waste policy section & 8.400 & 105 & Very low \\
\hline 8 & Facilities and infrastructure section & 15.900 & 71,5 & Very low \\
\hline
\end{tabular}


The calculation of the main managerial workload proposed by the regional apparatus seems imprecise, subjective and even some sections are actually irrational. The decrease in the value of the workload as a result of verification at the Office of Social Affairs, Family Planning, Women Empowerment and Child Protection is also because many job descriptions are categorized as staff or functional duties. It can be said that the burden of cation work feels heavy because they have to do staff work because the number of staff is very small. The number of civil servant staff for each section at the Social Service, Family Planning, Women's Empowerment and Child Protection are 24 staff.

The results of the research on the main managerial workload in West Bandung Regency, especially in the Environmental Service Office, show results that are not much different. Most of the workloads at the Environmental Agency are in the very low category.

Most of the main managerial workloads of the verification results fall into the very low category and only two sections are in the low category. Meanwhile, the main managerial workload results submitted by the Environment Agency are very high. The high results of the workload analysis submitted by the Environmental Agency, such as that carried out by regional officials in the DKI Jakarta Education Office and the Social, Family Planning, Women's Empowerment and Child Protection Services are caused by two things: First, unclear work results and methods The work formulated in the job description results in difficulties in calculating the actual workload, so that it is done with estimates only. This can be seen from the number of proposed workloads above 1250. Because if a person works above 1250 it means that he / she has to do overtime every day, especially those who convey more than 2000 hours. Second, because many of the job descriptions that are carried out are not patterns of behavior of structural officials, but patterns of staff duties (Walker \& Brewer, 2008:2) (Boyne et al., 2004:1). This is due to the small number of staff, which makes echelon IV officials carry out staff duties (Mohr, 1994:5). The number of staff for each section at the West Bandung Regency Environmental Service are 9 staff.

Based on the table above, it can be seen that the Kasi does not have enough civil servant staff to be managed. To assist each sub-section head, several non-civil servants have been appointed but because there is no prior training, these non-civil servants are less capable in processing and analyzing data. Thus, in fact the formation of echelon IV officials is more needed in carrying out staff duties than managerial duties as structural officials (Kim, 2005:1). The formation of positions vertically (hierarchy) is actually based on the need for supervision (H. P. Mintzberg, 1983:56). Based on the need for a range of control / supervision. If each sector with three sections only has 6 to 10 staff, the staff control should still be carried out within the control range of the head of the department. Therefore, the ideal form of public organizations in the future should prioritize the collaboration aspect with a focus on joint work rather than working alone. (Feldman, 2010:2). The organizational structure should be designed to achieve high efficiency and effectiveness (Burton et al., 2011:3) and supported by human resources who have intelligence, skills-based education, training and development (Hardiyansyah \& Rachmawati, 2018:1).

\section{CONCLUSION}

The government bureaucratic structure has not been prepared with objective considerations based on academic principles and is not based on the real needs of the implementation of government tasks and functions which are the scope of the duties of the regional apparatus. The formation of regional apparatus is still oriented towards creating the maximum structure in accordance with the provisions of the statutory regulations. The formulation of job descriptions in regional apparatus has not been in accordance with the standard of job description formulation because it does not contain clear content, methods and results / objectives. Likewise, the formulation of job descriptions does not reflect the behavior pattern of structural officials who carry out managerial functions. Structural official job descriptions do not have a clear pattern of behavior so that many echelon IV officials' job descriptions have lower job behavior than staff duty behavior. The main workload of echelon IV structural officials is mostly in the very low category. This implies that there are very few managerial needs at the echelon IV level. Most of the tasks performed by echelon IV officials are staff duties. Thus it can be concluded that the formation of bureaucratic structures at echelon IV level in regional apparatus is less efficient, where local governments must pay awards and facilities with echelon IV standards, but the work results can be produced or done by staff level. Therefore, to improve the efficiency and agility of regional apparatus in carrying out their duties and functions, the organizational structure of the regional apparatus led by echelon II structural officials does not need to be up to echelon IV level and sufficient to echelon III level (two levels). Seeing the number of employees in each echelon III is generally less than 10 people, so they are still capable of being controlled by the head of the field directly.

\section{ACKNOWLEDGMENTS}

Our gratitude goes to the Head of the DKI Jakarta Education Agency and his staff, the Head of the Organization Section of the Cimahi City Secretariat and the Head of the Organization Section of the Regional Secretariat of West Bandung Regency who have collaborated in the implementation of this research so that this research is carried out well. Do not forget to also express my gratitude to my fellow lecturers who have become discussion partners in the discussion of this research activity. 


\section{REFERENCES}

Barnard, C.I. (2006). The functions of the executive Chapter 2: The individual and organization. Emergence: Complexity \& Organization.

Boyne, G.A., Gould-Williams, J.S., Law, J. \&Walker, R. M. (2004). Toward the self-evaluating organization? An empirical test of the wildavsky model. Public Administration Review, 64, (4), 463-473. https:// doi.org/10.1111/j.1540-6210.2004.00392.x

Burton, R.M., Borge, O. \& Geraldin, D. (2011). Organizational Design: A Step-by-step Approach (2nd ed.). Cambridge: Cambridge University Press.

Feldman, M.S. (2010). Managing the organization of the future. Public Administration Review, 70(SUPPL. 1), s159-s163. https://doi.org/10.1111/j.15406210.2010.02262.x

Ghiselli, E.E., \& Siegel, J.P. (1972). Leadership and Managerial Success in Tall and Flat Organization Structures. Personnel Psychology, 25, (4), 617624. https://doi.org/10.1111/j.1744-6570.1972. tb02304.x

Gibson, J.L., Ivancevich, J.M. \& Donnelly, J.H. (1994). Organisasi. (S. Soekrisno \& A. Dharma, Eds.) (2nd ed.). Jakarta: Erlangga.

Hardiyansyah, H. \& Rachmawati, I. (2018). The Influence of Apparatus Resource Development on the Effectivity of Population Administration Service in Cianjur Regency, West Java. Jurnal Bina Praja, 10, (1), 69-80. https://doi.org/10.21787/ jbp.10.2018.69-80

Kim, S. (2005). Individual-level factors and organizational performance in government organizations. Journal of Public Administration Research and Theory, 15, (2), 245-261. https://doi.org/10.1093/jopart/ mui013
Martini, A., Tahir, M.I. \& Khairi, H. (2019). Organizational Model Application on Local Acency Organizational Struture. Jurnal Ilmu Sosial Dan Humaniora, 21, (2), 200-209. https:// doi.org/10.24198/sosiohumaniora.v21i2.21780

Mintzberg, H. (1980). Structure in 5's: A Synthesis of the Research on Organization Design. Management Science. https://doi.org/10.1287/mnsc.26.3.322

Mintzberg, H.P. (1983). Structure in Fives: Designing Effective Organization. New York: Prentice Hill.

Mohr, L.B. (1994). Authority in organizations: On the reconciliation of democracy and expertise. Journal of Public Administration Research and Theory, 4, (1), 49-65. https://doi.org/10.1093/oxfordjournals. jpart.a037193

Poels, F. (2003). Strategi Evaluasi Kerja dan Remunerasi: Bagaimana Merancang dan Menjalankan Sistem yang Efektif. (B. Hidayat, Ed.) (1st ed.). Jakarta: Gramedia Pustaka Utama.

Porter, L.W. \& Siegel, J. (1965). Relationships of Tall and Flat Organization Structures to the Satisfactions of Foreign Managers. Personnel Psychology, 18, (4), 379-392. https://doi. org/10.1111/j.1744-6570.1965.tb00293.x

Robbins, S.P. (1994). Teori Organisasi: Struktur, Desain dan Aplikasi. Jakarta: Arcan.

Suparman, N., Chandra, D. \& Sarri, A. (2019). Bureaucratic Behavior in the Implementation of Capital Expenditure Budget in the Office of Public Work and Spatial Planning of Sumedang Regency. Jurnal Bina Praja, (21), 99-109. https://doi. org/10.21787/jbp.11.2019.99-109

Walker, R. M., \& Brewer, G. A. (2008). An organizational echelon analysis of the determinants of red tape in public organizations. Public Administration Review, 68, (6), 1112-1127. https://doi. org/10.1111/j.1540-6210.2008.00959.x 